University of Rhode Island

DigitalCommons@URI

The Rhode Island Current Conditions Index

Economics

$1-2012$

\title{
Rhode Island Current Conditions Index - January 2012
}

Leonard Lardaro

University of Rhode Island, lardaro@uri.edu

Follow this and additional works at: https://digitalcommons.uri.edu/ricci

Part of the Econometrics Commons

Terms of Use

All rights reserved under copyright.

\section{Recommended Citation}

Lardaro, Leonard, "Rhode Island Current Conditions Index - January 2012" (2012). The Rhode Island Current Conditions Index. Paper 26.

https://digitalcommons.uri.edu/ricci/26

This Article is brought to you for free and open access by the Economics at DigitalCommons@URI. It has been accepted for inclusion in The Rhode Island Current Conditions Index by an authorized administrator of DigitalCommons@URI.For more information, please contact digitalcommons-group@uri.edu. 


\title{
CURRENT CONDITIONS INDEX LEONARD LARDARO, URI
}

\author{
Available Online: http:/ / www.llardaro.com/ current.htm (NEW URL) \\ Blog: http:/ / rieconomy.blogspot.com
}

VOL $\mathrm{XIX}$ NUMBER 2 J AN 2012
Rhode Island begins 2012 equipped with its newly revised labor market data. The prior data had painted a rather grim picture with Rhode Island's economy being essentially "dead in the water" for much of the second half of 2011. I had hoped the new data would show that things here were materially better than what we had been led to believe, especially concerning the abysmal performances of our Labor Force, Unemployment Rate, and the two employment series, Resident and Payroll Employment. wasn't sadly disappointed by the revised data. More to the point, I was alarmed by how much worse the actual performances of every one of those data series were. To summarize this very succinctly: the "good stuff" (the Labor Force, and both kinds of employment) was revised sharply lower while the "bad stuff" (the Unemployment Rate) was revised significantly higher. In light of these new data, we need to rethink much of what we had thought about our state's labor market performance. Check my Blog in the coming weeks for charts and posts about this

This does not necessarily mean that the overall picture of Rhode Island's economic performance in 2011 needs to be entirely overturned, though. The assessment of overall performance must

\begin{tabular}{|l|r|r|}
\hline \multicolumn{3}{|c|}{ CCI Indicators - \% Change } \\
\hline Government Employment & -1.3 & \\
\hline US Consumer Sentiment & 1.2 & Y \\
\hline Single-Unit Permits & 67.4 & Y \\
\hline Retail Sales & 3.5 & Y \\
\hline Employment Services Jobs & -7.6 & \\
\hline Priv. Serv-Prod Employment & -0.4 & \\
\hline Total Manufacturing Hours & 7.3 & Y \\
\hline Manufacturing Wage & 19.0 & Y \\
\hline Labor Force & -0.9 & \\
\hline Benefit Exhaustions & -10.7 & $Y$ \\
\hline New Claims & 8.2 & \\
\hline Unemployment Rate (change) & -0.5 & Y \\
\hline \multicolumn{2}{|c|}{ Y = I mproved Value } \\
\hline
\end{tabular}

be based on a broadly based set of indicators, which is precisely what the Current Conditions Index was designed to do. For 2011 , three monthly values were revised lower (January, November, and December), while one (March) increased. Based on these changes, Rhode Island's economy was a bit more "dead in the water" than I had earlier thought. In spite of this, our exceedingly tepid recovery did continue, albeit barely since the second half of 2011. Our bright spots, most notably Retail Sales, remained. It was our sore points that turned out to be quite a bit more sore. Sadly, or happily, depending on your preference, they still failed to improve, but by wider margins.

Let's begin indicator discussion with the bright spots. For J anuary, the Current Conditions Index registered a value of 58, as seven of the twelve indicators improved. January's $\mathrm{CCl}$ reading exceeded that from a year earlier, breaking a string of 10 consecutive misses. Rhode Island's recovery is now 23 months old.

Retail Sales improved for the fifth consecutive month $(+3.5 \%)$, starting off 2012 on a very positive note. US Consumer Sentiment rose in January $(1.2 \%)$, breaking a string of seven consecutive declines. Rhode Island's manufacturing sector showed significant strength, with Total Manufacturing Hours surging by 7.3 percent, based on greater employment and a sharply longer workweek, both of which helped to give some credibility to the dramatic increase of 19 percent in the Manufacturing Wage Benefit Exhaustions, a measure of long-term unemployment, fell again, by 10.7 percent. At the other end of the jobless spectrum, New Claims, a leading labor market indicator that includes layoffs, rose sharply, by 8.2 percent. Sadly, its uptrend appears to remain intact. Single-Unit Permits, which tracks new home construction, the most volatile of the $\mathrm{CCl}$ indicators, surged by 67.4 percent in January, obviously affected by weather.

Our Labor Force continued its more-horrible-than-we-knew performance in January $(-0.9 \%)$, and with this the decline in our Unemployment Rate was not welcome news. Employment Service Jobs, a leading labor market indicator that includes "temps," fell for a tenth time. Finally, Private ServiceProducing Employment declined again (its levels were revised lower) as did Government Employment.

CCI Over the Past 13 Months
100
90
80
60
50
40
30
20
10
0
2011 м01 2011м032011м05 2011м07 2011м09 2011м112012м01

The revised labor market data were finally released. Contrary to my hopes, these data were highly disappointing. It should now be painfully obvious to anyone who analyzes these data that many if not most of Rhode Island's economic problems are the result of its structural, not its cyclical, negatives. At the present time, Rhode Island finds itself once again being left behind as the pace of national economic activity accelerates. The days when our leaders were able to rationalize away our problems have now officially ended.

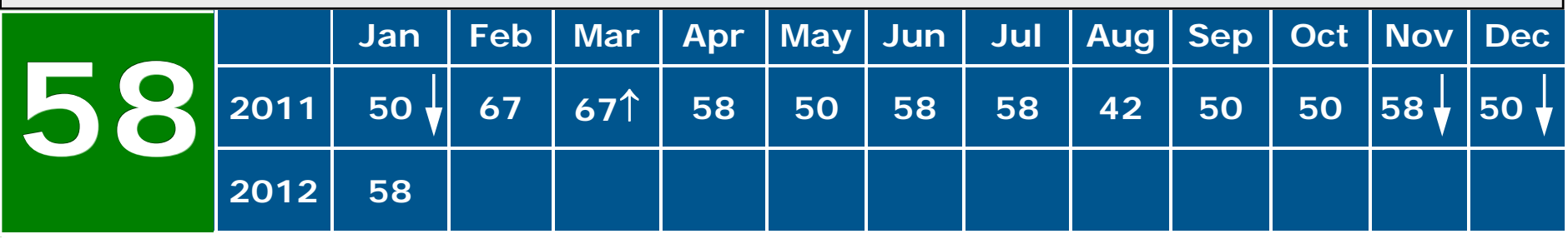

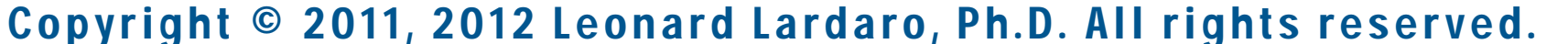

